\title{
Serious with the Wordplay: Battle Rap as a Critical Literacy Site and Model
}

Marcus W. Johnson, Ph.D. ${ }^{1 *}$

${ }^{1}$ Curriculum and Instruction, Texas State University

*mjohnson@txstate.edu

Received : 2020-07-25

Accepted : 2020-11-28

DOI: $10.46303 /$ jcve.2020.11

How to cite this paper: Johnson, M.W. (2020). Serious with the Wordplay: Battle Rap as a Critical Literacy Site and Model. Journal of Culture and Values in Education, 3(2), 24-41. doi.org/10.46303/jcve.2020.11

This is an Open Access article distributed under the terms of the Creative Commons Attribution 4.0 International license (https://creativecommons.org/licenses/by/4.0/)

\section{Abstract}

Critical scholars contend it must be the duty of those who are marginalized to create pedagogy that will empower themselves. As such, researchers continue to explore ways and means by which Black male students can engage with and enact literacy. While a significant amount of research has been conducted on hip-hop pedagogies and literacy, there lacks examination into how the specific element of battle rap functions as a location to cultivate the critical consciousness of students. This research seeks to highlight how the genre of battle rap can be a pedagogical tool of literary expression, while simultaneously shedding traditional standards of instruction which have constrained learning opportunities, particularly for Black male students. Critical literacy as a theoretical framework and critical discourse analysis (CDA) as a methodology are employed to advance battle rap as an effective instructional tool. Ultimately, this study seeks to privilege the educational experiences of Black male students and complex our interpretations of how language, literacy, and culture intersect and can be exercised in US classrooms.

Keywords: critical literacy, hip-hop pedagogy, battle rap, social studies, English language arts, Black male students 


\section{Introduction}

Traditional and simplistic approaches to literacy have failed to provide meaningful understandings of teaching and improving literacy for Black male students collectively. Tatum (2008) whose research centers around Black male literacy suggested, Black male students' best interests "are often ignored when developing or adopting instructional plans, selecting curricula, or examining students' [academic] placement" (p. 156). As a result, a number of scholars concerned with improving the educational experiences of Black male students and other underserved populations looked to teacher curricular and pedagogical attitudes and approaches to mitigate challenges (Milner, 2010). It is here that battle rap is presented as a pedagogical tool to assist in the development of critical literacy, specifically using English language arts and social studies as its hosts. This study argues that the lyrical genre of battle rap is composed of brilliant literary artists who culturally shape and fashion the English language, while simultaneously confronting societal issues. This study utilizes critical literacy (Freire, 1987) as its theoretical framework and Fairclough's (2013) critical discourse analysis (CDA) as its methodology. By examining a purposive sample of lyrics, it is advanced that battle rap as a pedagogical tool helps connect the "everydayness" of Black male students' lives to curricular and pedagogical decisions made inside the classroom.

Literacy is not simply contained within print mediums, but for groups such as African Americans, this includes spoken word and oral traditions as well. Scholars have viewed literacy as a shared and collective activity rather than an individual exercise, engaging with others towards community liberation (Freire \& Macedo, 1987; Green, 2013; Winn, 2008). Moreover, literacy - in its learning and practices, are far from contained within official schooling spaces. Multiple social contexts such as student's homes, communities, and recreational engagements are valuable sources to consider when making curricular and pedagogical choices (Moll, et al. 1992). By doing so, educators and students collaborate and even "conspire" to resist deficit-oriented interpretations and advance instruction and learning as uniquely responsive and situated to youth's most pressing needs and interests (Green, 2013; Keefer, 2017; Winn, 2010).

This study leans on previous research such as Kirkland (2009) who suggested "expressions of human experience exist in multiple forms, which can present new challenges and possibilities for English education" (p. 375). My stance towards improving the literacy outcomes of Black male students extends beyond academic achievement to also enriching their intellect to live fuller lives and ultimately contribute to the Black community (Wilson, 1992). Still, battle rap's distinctive attributes can not only serve Black male students but assist in the literacy improvement of all students. The focus on Black male student literacy doesn't negate the needs of young Black girls and adolescents and other marginalized populations. This study humbly but unapologetically acknowledges the deleterious educational efforts geared towards Black male students and aims to redress it in some capacity.

\section{Allow Me to Reintroduce Myself: What Is Battle Rap?}

Before continuing, it is essential to define battle rap. The need for a "re"introduction is due to the commercialization and dilution of hip-hop's intellectual and liberatory potency. The unbalanced scales of fun and entertainment vis-à-vis socially conscious rap should be corrected. Battle rap originates as a style of rapping or lyrical contest deriving from the genre and movement, hip-hop. It involves two rappers or artists competing to rhythmically out-duel 
each other. Researchers have found that battle rap carries elements of the West African Griot tradition of storytelling (Parker, 2020) "reimagined and sustained through such African American traditions as the blues, the dozens, and roasts" (Mavima, 2016, p. 89). Locations for battles taking place range from street corners and small neighborhood stores to now concert hall stages and online platforms such as YouTube, Caffeine, Twitch and pay-per-view options. Whether a battler uses jokes, insults, bravado, aggression, narrations, creative language, visual performance, or audience participation, the objective is to be victorious against your opponent displaying superior word play.

\section{Positionality of Author}

African American culture and in particular, hip-hop, has been a consistent influence upon my life. From reciting N.W.A. lyrics as an elementary student to citing Scarface and J. Cole in my doctoral dissertation, hip-hop informs the way I see myself and society. I have and continue to be inspired even academically by hip-hop. Because of hip-hop's significant growth as the most popular music genre (Lynch, 2018) and battle rap's association with one of its most prized skills, verbal performance, it makes sense to consider its instructional opportunities. As a teacher-educator, I strongly encourage preservice teachers to use popular culture as: a means to connect seemingly disparate phenomenon, a motivating tool, and as a form of resistance and agency.

As a researcher, I agree with Ladson-Billings (1995) that epistemological approaches reflect "who I am, what I believe, [and] what experiences I have had aligning with "membership in a marginalized racial/ cultural group" (p. 470). I lean towards Dillard's (2006) notions of endarkened epistemology which recognizes research as a responsibility to serve their community. When a researcher omits their voice, they are contributing to the "epistemological racism that lingers in the academy" (Hill, 2011, p. 90). What a paradigm "allows" for too often resembles power dynamics and hierarchies observed in classrooms of what is permissible and respected. I embark upon this research project to assist educators, researchers, and students alike to find and utilize our voices - carrying them from disorientation to embodied practice (Arkles, 2016). Identifying as an African American male and mindful of present social realities, the time is ripe to reconsider our orientations towards innovative pedagogical efforts.

\section{Literature Review}

Many approaches have been proposed to explain the context of Black male student literacy in US classrooms. Although the literature covers a wide array of redressing this issue, this review will focus on how teacher pedagogy, student's culture, and official curriculum can be reimagined and amalgamated.

\section{Culturally Relevant Pedagogy and Beyond}

Multiple educational approaches have sought to ameliorate the problematic circumstances facing underserved populations. Teacher quality proved to be a major focus of researchers looking to counter the racist and deficit-laden beliefs towards Black males students. Given that White, female, monolinguistic teachers make up 80 percent of the workforce (Hussar, et al., 2020) scholars highlighted the link between culture, teaching, and learning stressing an importance of cultural competence. Ladson-Billings (1995) advanced 
culturally relevant pedagogy which strives to empower "students intellectually, socially, emotionally, and politically by using cultural referents to impart knowledge, skills, and attitudes" (p. 17- 18). Culturally relevant pedagogy rests on three criteria: 1) students must experience academic success, 2) students must develop and maintain cultural competence, and c) students must acquire a critical consciousness through challenging the status quo of the social order. Similarly, culturally responsive pedagogy (Gay, 2000) is a concept that relies on the teacher understanding the background and language of the student and carefully integrating it with academic discourse to make it digestible for learners. Paris (2012) offered culturally sustaining pedagogy, which seeks to perpetuate and foster linguistic, literate, and cultural pluralism within schooling. More recent approaches such as curricular and pedagogical resuscitation (CPR) (Johnson \& Nicol, 2020) seeks to restore more of the Black "village" into the "school system" by teaching and learning through Black people's perspectives. These new and reformed directions seek to alleviate the disparity experienced by Black male students as traditional pedagogies tended to omit the history, contributions, and culture of Black Americans (Howard, 2014). It bears stating that efforts to amend attitudes and practices do not become essentialized and overdeterministic in the linkages of language and other cultural practices to certain racial and ethnic groups in approaching what it is we are seeking to sustain" (Paris, 2012, p. 95).

\section{"Authentic Spaces" for Black Male Expression}

Research involving Black male student literacy suggests, "the problem of how to increase literacy achievement of African Americans is embedded in social, cultural, economic, and historical dynamics" (Tatum, 2000, p. 53). Black male students in many ways face the same challenges in and out of school, as educational policies and practices fail to collectively support them. Therefore, this study strives to create authentic spaces in educational settings whereby Black students and educators "express their authentic selves and feel heard and validated versus stereotyped and judged" (Grier-Reed, 2010, p. 187). The examination of "authentic spaces" as a social phenomenon and strategy of Black resistance has been researched by numerous scholars (Akom, 2007; Chambers, 2014; Edwards, 2005; Grier-Reed, 2010; Solorzano, et al., 2000; Vickery, 2017). The concept of "authentic spaces" derives from terms such as "free spaces," "counter-spaces," "sanctuaries," "havens," and "spheres of cultural autonomy." It refers to a nonjudgmental, genuine, relational, and meaningful space on campus to integrate one's own personhood and humanity - counteracting isolation, stigma and stereotype threat (Grier-Reed, 2010).

Incorporating battle rap as a pedagogical tool has the potential to enable dialogue taking place in other recognized "authentic spaces" such as the Black barber shop to occur in schools. Concepts such as "virtual school bags" (Thomson, 2002) and funds of knowledge (Moll, et al., 1992) argue every child starts school with skills and knowledge learned from home, friends, and the world(s) in which they live. Unfortunately, the "virtual backpacks" of Black male students and the social and human capital of Black men are often unrecognized and unappreciated. Yet when educators operate from a position of viewing Black culture as replete with valuable resources just waiting to be exercised, this produces the antecedents of informal and formal "authentic spaces" for Black male students in school. 


\section{Hip-hop Pedagogy}

Hip-hop pedagogy is a powerful way of combining ELA and social studies. Significant scholarship speaks to the benefits of hip-hop pedagogy in increasing student achievement, attending to state standards and cultivating critical consciousness and activism (Dimitriadis, 2009; Emdin, 2013; Hill, 2009; Morrell \& Duncan-Andrade, 2002; Stovall, 2006). Also, hip-hop pedagogy is gaining more academic consideration due to its seemingly natural alignment with and extension of culturally relevant (Ladson-Billings, 1995), culturally responsive (Lee, 1998), culturally sustaining (Paris, 2012) and funds of knowledge (Moll, et al., 1992) pedagogies. Due to the hip-hop's embedded reflections of language, culture, society, and unique opportunities for meaning-making, it makes sense to join hip-hop pedagogy to ELA and social studies - not for more challenges but more instructional dexterity and efficiency. Therefore, battle rap's intricate text, verbal performance, and overall presentation offer more accurate and explicit ways of eliciting engagement and improved learning spaces (Parker, 2020).

\section{Empowering Social Studies}

The task of nurturing citizens with the values, knowledge, skills, and beliefs in order to serve a democratic society is heavily bestowed on social studies. If properly accomplished, social studies helps young people recognize their positions within a larger community and attempt to make sense of how society is structured (Saracho \& Sodek, 2007). If educators are to "help young people develop the ability to make informed and reasoned decisions for the public good as citizens of a culturally diverse, democratic society in an interdependent world" (NCSS, 1994, p.3) critical literacy has to be involved in our teaching and learning. Yet, critique in-and-of-itself is not the goal - but the end of all knowledge should result in service to others. In this case, empowering social studies as curricular and pedagogical resuscitation - CPR (Johnson \& Nicol, 2020) insists, would privilege Black experiences and advocate for the subject's validity in an era of high-stakes testing. Studies conducted of social studies curriculum and pedagogy demonstrates the plethora of Eurocentric, White, male perspectives laden classrooms (Johnson, 2019; Brown \& Brown, 2010; Woodson, 2016). Therefore, critical approaches to social studies developed explicitly exploring issues such as power, agency, and culture. Efforts that involve critical social studies pedagogies create unique spaces where teacher and student deconstruct and reconstruct ontologies and cultivate critical consciousness (Magill \& Salinas, 2019). Educators pursuing critical social studies expose cracks within official curriculum (DeLeon, 2014) to walk the tightrope alongside their students coconstructing learning opportunities (Castro, et al., 2015). In order to continue working towards social studies operating as a beacon of emancipatory visions and realties, content knowledge, and purpose / spirit (Barton \& Levstik, 2003; Dillard, 2006; Johnson \& Nicol, 2020) must be attended to in preservice and teacher development programs.

\section{Integrating English Language Arts and Social Studies Curriculum}

Curriculum integration has been a useful method for addressing curricular imbalances between disciplines (Brophy, et al., 2012). Social studies continues to fight for classroom instructional time in an era of accountability. As a result, Yearta (2019) expressed "integration is no longer an ideal; it is a necessity" (p. 215) for teachers with ever-increasing responsibilities. Content integration according to Huck (2019) received increased attention due to No Child Left Behind (NCLB) and Common Core State Standards (CCSS). To revive social 
studies in classrooms and shift beyond mere functional literacy approaches, educators and scholars have looked to integrating ELA and social studies content (Obenchain \& Pennington, 2015).

Effective integration of ELA and social studies doesn't equate to simply blending the two subjects together. To assist in this integrative approach, Alleman and Brophy (2010) outline multiple principles of desirable integration and undesirable integration - primarily based on promoting or stifling progress toward specific content goals and standards. Regardless, educators and researchers alike have come to an understanding and quasi-negotiation that in order for social studies to receive its deserved attention, integration into other subjects, in particular ELA, is advantageous (Brophy \& Alleman, 1991; Hill, 2009; Kinniburgh \& Busby, 2008; VanFossen, 2005). This wouldn't be unfamiliar to social studies as a subject because "social studies is, in and of itself, an example of integrated content" (Huck, 2019, p. 2) as it "builds on and allies itself with the analytic work of critical literacy" (Jewett, 2007 p. 169).

\section{Theoretical Framework}

\section{Critical literacy}

This study is guided by the theoretical framework of critical literacy (Freire, 1970/ 1996). Critical literacy provides a lens whereby instructional practices can not only bridge but privilege Black identities, communities, and epistemologies within schooling. Critical literacy assists in disrupting traditional learning ideologies and methods which have stunted literacy opportunities of far too many Black youth.

Early scholarship related to critical literacy is generally credited to Paulo Freire (1970/ 1996) and more specifically Freire and Macedo (1987), who argued that it is vital to understand the political and economic context in which texts are created and maintained, as well as how texts are socially constructed. Texts do not exist in isolation but carry with them powerful, culturally-embedded markers. Freire urged to not just read the word (develop basic literacy skills) but read the world (assess one's political position within society). In essence, Freire's notion of critical consciousness explains how those oppressed learn to critically analyze their sociopolitical conditions and act to change them in pursuit of justice. Identifying the recognizable and latent distinctions within language and Black youth's consumption and production of such helps decolonize the classroom (Emdin, 2016).

Further analysis uncovers that without firm theory considering the significance of texts for Black students, even ideal instructional methods miss the mark (Tatum, 2008). By utilizing critical literacy, the aim is to help uncover and interrupt hegemonic practices in oral, written, and popular culture contexts that have taken up an all-too-comfortable residence within standard curriculum and pedagogy. Critical literacy maintains incorporating the language used in students' everyday activities as pivotal to learning. As Wood and Jocius (2013) put forth applying critical literacy "can create a learning environment that raises expectations for academic achievement by challenging traditional notions of literacy instruction" (p. 663) for Black students. Critical literacy also asserts that outside-of-school experiences hold intellectual value that can be utilized inside the classroom. As such, critical literacy explicitly orientates itself as a redistributive and recognitive model of interrogating what is considered "official knowledge" (Luke, 2012) and enables (re)energizing literacy practices for Black male students. 


\section{Methodology}

\section{Critical Discourse Analysis}

The central underpinning of critical discourse analysis (CDA) is the existence of diverse interpretations of texts (Fairclough, 2013). Tensions continue to exist amongst the power associated with certain interpretations. CDA was applied to this study in order to enable vigorous and authentic assessment of what is meant by the language used via battle rappers and the hip-hop/ battle rap community. CDA views the study of language as a form of social practice. Texts, language, and communication are shaped by larger contexts of society (Fairclough, 2013).

CDA is determined by the link between language, power, and ideology (Machin and Mayr, 2012). In alignment with critical literacy, CDA asserts that experience is "produced under specific basic conditions of learning and illuminates the role that pedagogy plays as part of a struggle over assigned meanings, modes of expression, and directions of desire" (Giroux, 2011, p.4). Therefore, CDA explores the syntax and terminology used in its development to its dissemination and understanding to a wider audience. Parts of speech, tone, stance, and gestures is also considered for a more comprehensive analysis.

This study follows Fairclough's (1996) three dimensions of CDA: 1) description concerned with formal properties and associations of the text; 2 ) interpretation - focus on relationship between text and interaction, basically how and why one uses certain kind of language; and 3) explanation - attention paid to the relationship between interaction, social context, and for the purposes of this study, how it connects to curricular and pedagogical purposes. In some instances, two or more dimensions of CDA can be revealed simultaneously depending on context. This project seeks to illuminate a rarely-tapped curricular and pedagogical resource, "seeing in texts and social practices the hidden, or partially hidden, discourse associated with it" (Poole, 2010, p. 140). In doing so, this study complexes our interpretations of how language, literacy, and culture can be exercised in US classrooms.

Figure 1: Fairclough's Three-dimensional Framework for Analysis of Discourse

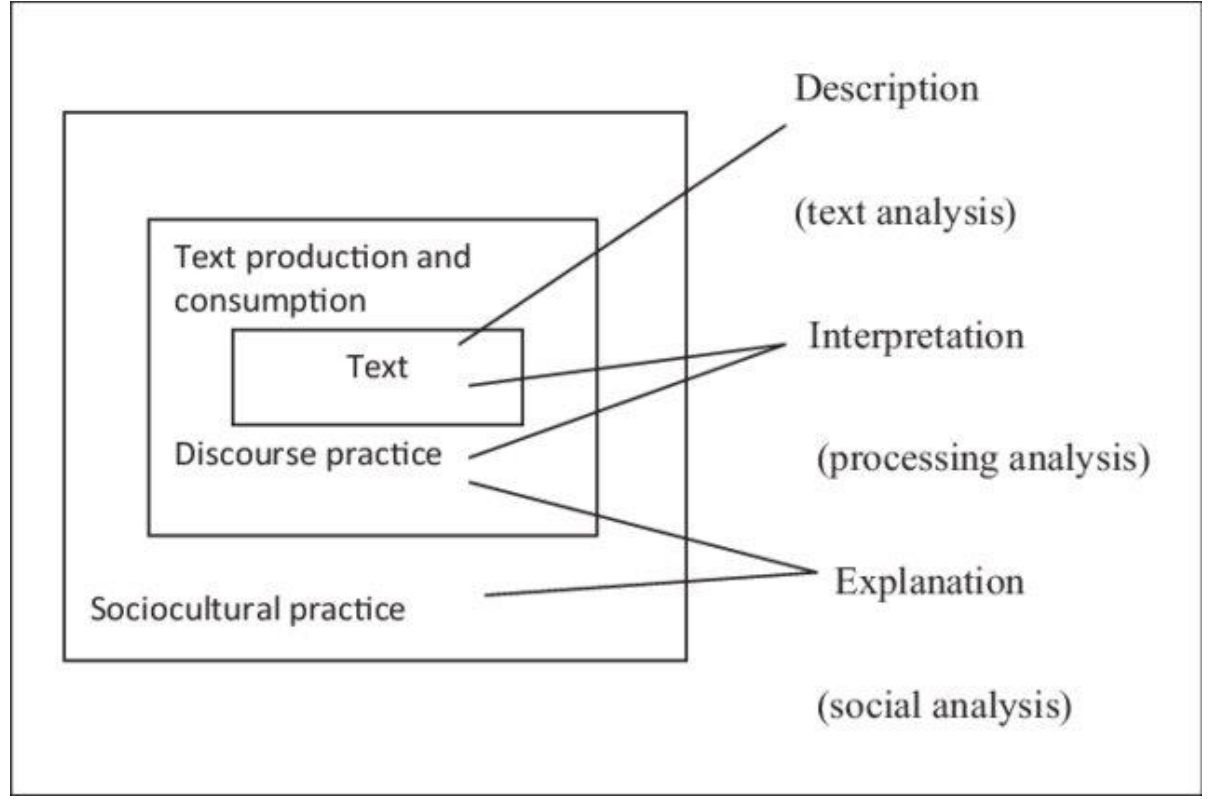

Source: Fairclough (2013). 
Convenience sampling was utilized to select the specific battles for this study. I regularly participate on Black Compass Media's Discord (a digital platform) discussing battle rap with well-versed and knowledgeable individuals on the topic. I considered, "What battles consists of 'socially conscious' material?" Amongst those suggested, the final selections were due to the highlighted ideological differences and approaches of the battle rappers. These selections exemplify and represent battle rap's foremost potential in ELA and social studies classrooms. The key objective for highlighting various snippets of battle rap lyrics is to provide a lens for how its implementation can address state accountability standards while cultivating students' critical consciousness and privileging Black cultural identities, experiences, and imaginations.

\section{Analysis sample}

Let's get to choppin' this fable.

You're a fake new Tupac and we're fatal.

- Loaded Lux vs. Calicoe (Ultimate Rap League, 2012, $3^{\text {rd }}$ round)

(Description) Lux starts by offering to discuss a particular narrative. (Interpretation) Lux addresses what he believes to be a false comparison of his opponent, Calicoe, to the legendary artist and activist, Tupac Shakur. Lux then pulls off a linguistic triple entendre: 1) insisting that if Calicoe is the new Tupac, the rest of us are doomed, 2) his method of dissecting Calicoe's character will be precise and vicious, and 3) Fatal Hussein was a member of Tupac's crew, The Outlawz. (Explanation) Tupac's life similar to other historical figures exists within the tensions of what it means to be a US citizen and practice civic action - which can address how students view and take up civic virtues and democratic principles themselves.

\section{Explicating Examples}

The following are excerpts deriving from three separate battle rap contests: Oops vs. Daylyt (Rare Breed Entertainment, 2015), Loso vs. B Dot (ShrugLife Network, 2017), and Danny Myers vs. Xcel (King of the Dot Entertainment, 2015). It is general custom that battle rap matches are composed of three rounds, wherein each artist alternates opportunities to speak. Therefore, this study presents examples in the form of three rounds also.

\section{Top of Round 1}

I'm tryin' to change the game as far as we know now

I'm the passionate, activist version of Nino Brown

I'm Martin Luther, Marcus Garvey, mixed with John Gotti, Malcolm X, Mr. Clark

Strapped with a piece (peace) like Gandhi

They say, "Ooops you contradicting yourself because you freedom fightin' but you stay with the heat." I mean, I motivate my people but even Mother Teresa stayed with the peace (piece) 
So you can get that open hand disorder [?] you'll need prayers my $\mathrm{G}$ Cause if I waved this black power, you gon' be prayin' for peace.

- Ooops vs. Daylyt (Rare Breed Entertainment, 2015, $1^{\text {st }}$ round)

By simply surveying the text, prominent and popular names leap off the paper: Nino Brown (fictional character in movie, New Jack City), Martin Luther [King Jr.], Marcus Garvey, John Gotti, Malcolm X, Mr. Clark (fictional character in the movie, Lean On Me), Gandhi, and Mother Teresa. Characteristic of battle rapping style, Ooops then displays literary wordplay by utilizing the homonyms, peace and piece (acronym for a handgun).

Also, Ooops (who once served as a state representative in Missouri and was nominated for an Oscar in 2020) is seemingly expressing the internal and external pressures he feels as a community activist. Up for consideration in his mind, are the perceptions, assumptions, and erasure of binaries related to non-violence and peace versus self-defense. Covered within just this example are notions tied to citizenship and identity (social studies) and autoethnography and creative prose (ELA).

\section{Bottom of Round 1}

I start Crippin', became a C (sea) god, it's not Poseidon I was afraid of the real world, so I use the block for hidin' One thing I could do was kill every enemy in my hood but we couldn't stop the sirens

R.I.P. Mooky, R.I.P. Kalo, them cop shots was flyin' All I kept sayin' was, "Goddamn the block is dyin'"

-Daylyt vs. Ooops (Rare Breed Entertainment, 2015, $3^{\text {rd }}$ round)

In this excerpt of Daylyt's third round against Ooops, he provides insight into his upbringing and narrates certain community activities of which he is intimately familiar. He indicates his joining of the Crips (street organization / gang; originally beginning as Community Revolution in Progress). He goes on to play on words by stating he "became a ' $C$ ' god," reaching prominence within the gang. However, he contrasts his gang affiliation to the mythical Greek god of the sea stating, "[he's] not Poseidon." He continues by using the word, "sirens" as a homograph and alluding Greek mythology - articulating no matter how many of his "enemies" he could get rid of, "sirens" (the sounds of law enforcement and ambulances) inundated his neighborhood. Sirens in Greek mythology were akin to mermaids who lured sailors with their beautiful voices to their ultimate doom.

Daylyt then follows a noted tradition within Black culture - paying homage to those who have passed on. Interestingly, he alludes to the police being responsible for the deaths of the two individuals indicated. So, high risk factors involved both other rival gangs and law enforcement. Ultimately, this section of Daylyt's round speaks to his articulation of the prevalence of danger, death and the intricate navigation it took to come of age in his neighborhood. In terms of subjects, this piece uses figurative language (ELA) and examination of and contributions towards one's community and Greek Mythology (social studies). 


\section{Top of Round 2}

You an actor turned rapper, I was thinkin', "Is this straight?

He wanna discredit all those believin'" I'm sayin', Is this a mistake?"

But no Biggie, I Hit 'Em Up for tryin' to diss Faith

But he ain't wanna dead the beef like the fifth plague.

-Loso vs. B Dot (ShrugLife Network, 2017, $1^{\text {st }}$ round)

In this exchange, Loso is emphasizing the competing ideologies of Christianity that he ascribes to and Kemetic Science (Ancient Egyptian spirituality) of which his opponent, B Dot represents. Loso reveals how he attempted to contact (hit someone up) B Dot to discuss the issue; yet he cunningly uses the names of hip-hop musical artists that were infamously engaged in a relationship quarrel - Notorious BIG (Biggie Smalls), Tupac Shakur (Hit 'Em Up, a song that Tupac mentioned the affair) and acclaimed r\&b artist, Faith Evans - Notorious BIG's fiancé and subject of Tupac's attention. Nevertheless, Loso claims that his attempts to avoid conflict and reach an understanding (dead the beef) were dismissed by B Dot. He uses the literary artform of analogy and historical mythology by referring to the Fifth Plague - a mysterious and infectious disease that eradicated Egyptians' livestock in the $18^{\text {th }}$ century. Here we can make ties to conflict resolution and philosophical debate (social studies) and the use of figurative language (ELA) to express one's thoughts and feelings.

\section{Bottom of Round 2}

All my queens I need y'all to look up Henrietta, she died a while back But her cells they still extract And give them to other races and replacements for the things they lack See this is scientific facts This isn't just rap I'm not talkin' 'bout the $\mathrm{n}$ * from Queens when I tell my queens that they DNA is bridgin' the gap.

-B Dot vs. Loso (ShrugLife Network, 2017, $2^{\text {nd }}$ round)

B Dot, who adheres to PanAfricanism - a collective idea of strengthening the bonds of amongst indigenous and diasporic ethnic groups of African descent, calls for the attention of Black women, identifying them as queens. Queen is a term used to empower and uplift Black women who according to Malcolm X (1962) is the most disrespected, unprotected, and neglected person in America. He encourages them to research another Black woman, Henrietta Lacks. During Lacks' battle with cervical cancer in the early 1950s, her cells were cultured by doctors without permission. Her cells, known as the HeLa cell line, are still being utilized as a source of medical data and science today. He goes on to make a humorous distinction of his referencing of queens and DNA because the name of another popular battler rapper, DNA, lives in Queens, New York. This snippet of B Dot's round incorporates informative writing (ELA) and issues pertaining to citizenship, and the historical figure, Henrietta Lacks (social studies). 


\section{Top of Round 3}

When I zone in, I make grown men bones bend Every figure hard in my circle welcome to Stonehenge You one dimensional, how can there be limits with a god? You Cesare Borgia you just portray the image of a god But it's cool, he catchin' all razor blades when my squad spot him They only gon' find $5 \%$ of the god body

-Danny Myers vs. Xcel (King of the Dot Entertainment, 2015, $1^{\text {st }}$ round)

Danny Myers (referred to as Bar God) pens that when he is "zoned in" or at his optimal, flowlike state, no one can stop him. He then refers to his circle of friends as being equally as strong and unyielding as the prehistorical monuments at Stonehenge. He goes on to criticize Xcel's battle rap style as simplistic. It is widely understood that ascending to the level of God $\mathrm{MC}$ (considered superior with lyrical rhymes and performance), is the goal within hip-hop and battle rap. Myers persists in his taunting, suggesting that Xcel is like Cesare Borgia, who was a $15^{\text {th }}$ century, Spanish-Italian politician rumored to be the popular modern White image painted of Jesus.

In keeping within religious and ideological themes, Danny explains that his crew will devastate Xcel to the point of only discovering five percent of his body. The Nation of Gods and Earths or Five Percenters is a movement or way of life stemming from the Nation of Islam. The Five Percent Nation, which Xcel is a member, professes to cultivate Black people's self-knowledge, unity, and ability to understand the universe using Supreme Mathematics or science. Many of hip-hop's most influential artists (i.e. Rakim, members of the Wu-Tang Clan, Busta Rhymes and Jay-Z) are affiliated with this movement - the five percent who know truth and are resolved to enlightening the other eighty-five percent of the world's population. Nestled amongst this selected text are narrative structures conveying information (ELA) and references of a geographical marker, historical figure, and a major US social and ideological movement (social studies).

\section{Bottom of Round 3}

These next lines, analyze with your mind's third eye vision

Cause you was on that same card, vs Cali Smoov dry snitchin'

You said you sell crack, you sell weed, you sell dope, coke and other unnecessary antidotes

Whoa, I mean my $n^{*}$ who you convincing?

I understand you gotta tell $n^{*}$ just how you get it

But that shit don't constitute you ignoring the 5th Amendment.

-Xcel vs. Danny Myers (King of the Dot Entertainment, 2015, $3^{\text {rd }}$ round)

Xcel urges Danny Myers to listen closely with his "third eye" referring to one's pineal gland or gateway to higher consciousness and enlightenment. Xcel then recalls Myers in a previous battle overexaggerating and more damning, exposing personal business. In the end, even though Xcel understands why Danny divulged information to his fan base, he is still 
reprimanded for publicly confessing his "illegal" activities. Here one can elicit learning opportunities about our nation's Constitution and its amendments (social studies) as well as persuasive writing (ELA).

\section{Embracing Battle Rap as a Viable Pedagogical Tool}

Each of the above selections underscore how various concepts of literacy (ELA) and critical literacy in the form of social studies are intertwined in the texts. The creativity with words is dynamic and laudable. Moreover, we are able to witness how knowledge, multiple viewpoints, and narratives commonly ignored in textbooks are cornerstones of battle rap exchanges. Often disrupting standard patterns of teacher pedagogy (Smith, 2020) and implementing popular culture, in this case battle rap within teaching, are accompanied by questions of appropriateness and availability. When asked where hip-hop pedagogies fit within sanctioned standards, Hall's (2017) consistent reply is, "where you make space for it" (p. 343). Lawlor (2008) urges us to mimic rats by finding openings and the slightest of educational cracks to teach in humanizing ways. Rejecting monolithic perceptions of Black male youth, it is still possible these student's prior and constantly adapting knowledge can be positioned as introductions or connections to concepts cited in battle rap. This study prioritizes educators' willingness to consider battle rap as an instructional instrument than the formalities of its implementation. That given, some methods and suggestions are provided next to assist battle rap and hip-hop pedagogies "fit" within classrooms.

There are clear connections between C3 Framework themes (NCSS, 2013) and battle rap's potential in classrooms such as: inquiry, evaluating sources (battle rap) as evidence to engage in perspective-taking, and communicating conclusions and taking informed action to cultivate students' critical consciousness. Additionally, be it classroom battle pedagogy (Parker, 2020) - students participating in rhyming debates, text analysis of battel rap content, simulation, or various supplementary methods, it is believed that battle rap instructional activities can resonate with students, their culture, and inject joy and fun into classrooms, which is falsely aligned with anti-intellectualism. Moving forward, future research could involve creating a linked reference resource or repository for teachers based on social studies and ELA elements embedded in battle rap lyrics.

\section{Limitations}

The language employed within battle rap can be considered problematic and explicit. Nonetheless, many of the societal issues Black male students experience individually and collectively extend beyond the problematic and in certain cases are outright violent. I consider battle rap artists to be in unique and distinct sociocultural and political positions. They carry out the important custom of storytelling among the African diasporic community (Hill, 2009; Mavima, 2016). Inherit within this storytelling, are notions of what Foucault (2001) referred to as parrhesia - the practice of truth-telling. This study is geared towards addressing students' realities and reducing the gap between in-school teaching and learning and that occurring "within communities physically outside of, and oftentimes beyond, the school" (Emdin, 2016, p. 30).

Another possible limitation can be the small sample size used for this study. While there is a significant amount of battle rap matches and lyrics to choose from, it is essential for teachers to mine and carefully select battle rap contests and/ or prepare students for possibly 
sensitive material. Contests can be viewed on the various platforms such as YouTube by searching "Ultimate Rap League," "Rare Breed Ent.," "Black Ice Cartel" "Queen of the Ring," "King of the Dot," and other battle rap channels. Many contests have been transcribed into written text and can be viewed on websites such as Genius.com.

\section{Conclusion}

This study set out to draw attention to the pedagogical possibilities of utilizing battle rap as a way to nurture critical literacy. English language arts and social studies were identified as the instructional subjects battle rap could efficiently be introduced to and implemented within. It is acknowledged that teachers are weighted by the demands of high stakes testing and accountability measures in language arts coupled with the "paucity of tools and texts available to represent [social studies and] history" (Willis, 2011, p. 139). King (2019) asked researchers to locate "unofficial and unconventional social studies spaces" (p. 91) where Black students learn in critical and enjoyable ways. As Wood and Jocius (2013) noted, educators can struggle to obtain texts written by and featuring Black boys and men. Yet, even when found, research has demonstrated that covering critical issues tended to center around events of the past as opposed to examining current realities (Vlach, 2019). Accordingly, this study presents battle rap as a scholastic instrument to address the concerns mentioned above.

Studies have demonstrated how hip-hop pedagogies have benefitted student experiences and academic outcomes (Dimitriadis, 2009; Hill, 2009; Morrell \& Duncan-Andrade, 2002; Parker, 2020). Due to the pioneering efforts of levying battle rap as an academic tool, educators must critically evaluate intended and unintended implications since new and nontraditional learning opportunities often engenders new obstacles (Newton, et al., 2020; Petchaur, 2011). Nevertheless, cultivation of students' critical consciousness continues to be warranted given our sociopolitical times. Battle rap powerfully speaks to some of students' most salient experiences and identities. Properly understood and organized, battle rap boldly acts as an educational resource with the means of empowering students, specifically Black male students, academically and around issues of justice.

\section{Acknowledgements}

I would like to thank Black Compass Media and those who participate on their various platforms for their thoughtful suggestions. 


\section{References}

Akom, A. A. (2007). Free spaces: Excavating race, class, and gender among urban schools and communities. International Journal of Qualitative Studies in Education, 20(6), 611-616. http://dx.doi.org/10.1080/09518390701630700

Alleman, J., \& Brophy, J. (2010). Effective integration of social studies and literacy. In M. E. McGuire \& B. Cole (Eds.), Making a difference: Revitalizing elementary social studies (pp. 51-65). National Council for the Social Studies.

Arkles, R. (2016). Finding my researcher voice: From disorientation to embodied practice. In S. Segal \& C. Jankelson (Eds.), Face to face with practice: Existential forms of research for management inquiry (pp. 69-85). Taylor \& Francis Ltd.

Barton, K. C., \& Levstik, L. S. (2003). Why don't more history teachers engage students in interpretation?. Social Education, 67(6), 358-358.

Brophy, J. E., \& Alleman, J. E. (1991). A caveat: Curriculum integration isn't always a good idea. Educational Leadership, 49(2), 66.

Brophy, J., Alleman, J., \& Halvorsen, A. (2012). Powerful social studies for elementary students. Cengage Learning.

Brown, K. D., \& Brown, A. L. (2010). Silenced memories: An examination of the sociocultural knowledge on race and racial violence in official school curriculum. Equity \& Excellence in Education, 43(2), 139-154. http://dx.doi.org/10.1080/10665681003719590.

Castro, A. J., Hawkman, A. M., \& Diaz, J. (2015). Teaching race in high school social studies: Lessons from the field. In P. Chandler (Ed.), Doing race in social studies: Critical perspectives (pp. 1-10). Information Age Publishing.

Chambers, A. D. (2014). Cultural solidarity and the free space of the Black fraternity. Journal of Pan African Studies, 7(3), 254-281.

DeLeon, A. (2014). Capitalism is for the body, religion is for the soul. In E. W. Ross (Ed.), Social studies curriculum: Purposes, problems, and possibilities (4th ed., pp. 71-89). State University of New York Press.

Dillard, C. B. (2006). When the music changes, so should the dance: Cultural and spiritual considerations in paradigm 'proliferation'. International Journal of Qualitative Studies in Education, 19(1), 59-76. https://doi.org/10.1080/09518390500450185

Dimitriadis, G. (2009). Performing identity/performing culture: Hip hop as text, pedagogy, and lived practice (Vol. 1). Peter Lang.

Edwards, D. (2005). " Doing hair" and literacy in an afterschool reading and writing workshop for African-American adolescent girls. Afterschool Matters, 4, 42-50.

Emdin, C. (2013 ). The rap cypher, the battle, and reality pedagogy: Developing communication and argumentation in urban science education. In M. L. Hill \& E. Petchauer (Eds.), Schooling hip-hop: Expanding hip-hop based education across the curriculum (pp. 11-27). Teachers College Press.

Emdin, C. (2016). For White folks who teach in the hood... and the rest of $y^{\prime}$ all too: Reality pedagogy and urban education. Beacon Press.

Fairclough, N. (2013). Critical discourse analysis: The critical study of language. Routledge.

Foucault, M. (2001). Fearless speech. (J. Pearson, Ed.). Semiotext.

Freire, P. (1970/ 1996). Pedagogy of the oppressed (revised). Continuum.

Freire, P., \& Macedo, D. (1987). Literacy: Reading the word and the world. Bergin \& Garvey. 
Gay, G. (2000). Culturally responsive teaching: Theory, research, and practice. Teachers College Press.

Giroux, H. A. (2020). On critical pedagogy. Bloomsbury Publishing.

Green, K. L. (2013). "The way we hear ourselves is different from the way others hear us": Exploring the literate identities of a Black radio youth collective. Equity \& Excellence in Education, 46(3), 315-326. http://dx.doi.org/10.1080/10665684.2013.808506

Grier-Reed, T. L. (2010). The African American student network: Creating sanctuaries and counterspaces for coping with racial microaggressions in higher education settings. The Journal of Humanistic Counseling, Education and Development, 49(2), 181-188. http://dx.doi.org/10.1002/j.2161-1939.2010.tb00096.x

Groch, S. (2001). Free spaces: Creating oppositional consciousness in the disability rights movement. In J. Mansbridge and A. Morris (eds.). Oppositional consciousness: The subjective roots of protest (pp.65-98). University of Chicago Press.

Hall, H. B. (2017). Deeper than rap: Expanding conceptions of hip-hop culture and pedagogy in the English language arts classroom. Research in the Teaching of English, 51(3), 341-350.

Hill, M. L. (2009). Wounded healing: Forming a storytelling community in hip-hop lit. Teachers College Record, 111(1), 248-293.

Hill, T. (2011). Every closed eye ain't sleep: African American perspectives on the achievement gap. Rowman \& Littlefield.

Howard, T. C. (2014). Black male(d): Peril and promise in the education of African American males. Teachers College Press.

Huck, A. (2019). Elementary social studies content integration in CCLA: An analysis of content integration, The Social Studies, 110(1), 1-16.

Hussar, B., Zhang, J., Hein, S., Wang, K., Roberts, A., Cui, J., et al. (2020). The Condition of Education 2020 (NCES 2020-144). Washington, DC: U.S. Department of Education, National Center for Education Statistics. https://nces.ed.gov/pubsearch/ pubsinfo.asp?pubid=2020144.

Jewett, S. (2007). The stories of people's lives: Thematic investigations and the development of a critical social studies, The Social Studies, 98(4), 165-171. https://doi.org/10.3200/TSSS.98.4.165-173

Johnson, M. W. (2019). Trump, Kaepernick, and MLK as "maybe citizens": Early elementary African American males' analysis of citizenship. Theory \& Research in Social Education, 47(3), 1-22. https://doi.org/10.1080/00933104.2019.1582381

Johnson, M. W. \& Nicol, M.W. (2020). Introducing curricular and pedagogical resuscitation (CPR): A Black approach to reviving the self and collective through social studies. Urban Education, 1-25, https://doi.org/10.1177\%2F0042085920948948

Keefer, N. (2017). The Persistence of Deficit Thinking Among Social Studies Educators. Journal of Social Studies Education Research, 8(3), 50- 75.

King, L. J. (2019). Unofficial and unconventional social studies spaces for students of color. The Journal of Social Studies Research, 43(2), 91- 95. http://dx.doi.org/10.1016/j.jssr.2019.03.001

Kinniburgh, L. H., \& Busby, R. S. (2008). No social studies left behind: Integrating social studies during the elementary literacy block. Journal of Content Area Reading, 7(1), 55-88. 
Kirkland, D. E. (2011). Listening to echoes: Teaching young black men literacy and the distraction of ELA standards. Language Arts, 88(5), 373.

Ladson-Billings, G. (1995). Toward a theory of culturally relevant pedagogy. American Educational Research Journal, 32(3), 465-491. http://dx.doi.org/10.3102/ 00028312032003465

Lawlor, L. (2008) Following the rats: Becoming-animal in Deleuze and Guattari. SubStance 37(3), 169-187. https://doi.org/10.1353/sub.0.0016

Lee, C. D. (1998). Culturally responsive pedagogy and performance-based assessment. Journal of Negro Education, 268-279. http://dx.doi.org/10.2307/2668195

Luke, A. (2012). Critical literacy: Foundational notes. Theory into practice, 51(1), 4-11. http://dx.doi.org/10.1080/00405841.2012.636324

Lynch, J. (2018, January 04). For the first time in history, hip-hop has surpassed rock to become the most popular music genre, according to Nielson. Business Insider. https://www.businessinsider.com/hip-hop-passes-rock-most-popular-music-genrenielsen-2018-1

Machin, D, Mayr, A (2012) Critical discourse studies: A Multimodal Approach. SAGE.

Magill, K. R., \& Salinas, C. (2019). The primacy of relation: Social studies teachers and the praxis of critical pedagogy. Theory \& Research in Social Education, 47(1), 1-28. http://dx.doi.org/10.1080/00933104.2018.1519476

Malcolm, X. (1962, May 5). Who taught you to hate yourself? Funeral Service of Ronald Stokes. https//:www.genius.com/Malcolm-x-who-taught-you-to-hate-yourselfannotated.

Mavima, S. (2016). Bigger by the dozens: The prevalence of Afro-based tradition in battle rap. Journal of Hip Hop Studies, 3(1), 86-105.

Milner IV, H. R. (2010). What does teacher education have to do with teaching? Implications for diversity studies. Journal of Teacher Education, 61(1-2), 118-131. http://dx.doi.org/10.1177/0022487109347670

Moll, L. C., Amanti, C., Neff, D., \& Gonzalez, N. (1992). Funds of knowledge for teaching: Using a qualitative approach to connect homes and classrooms. Theory into practice, 31(2), 132-141. https://doi.org/10.2307/821822

Morrell, E., \& Duncan-Andrade, J. M. (2002). Promoting academic literacy with urban youth through engaging hip-hop culture. English Journal, 91(6), 88-92. http://dx.doi.org/ $10.2307 / 821822$

National Council for the Social Studies. (1994). Curriculum standards for social studies. National Council for Social Studies.

National Council for the Social Studies. (2013). Social studies for the next generation: Purposes, practices, and implications of the college, career, and civic life (C3) framework for social studies state standards. National Council for the Social Studies.

Newton, J., Williams, M., \& Feeney, D. (2020). Implementing non-traditional assessment strategies in teacher preparation: Opportunities and challenges. Journal of Culture and Values in Education, 3, 39-51. https://doi.org/10.46303/jcve.03.01.3

Obenchain, K. M., \& Pennington, J. L. (2015). Educating for critical democratic literacy: Integrating social studies and literacy in the elementary classroom. Routledge. 
Paris, D. (2012). Culturally sustaining pedagogy: A needed change in stance, terminology, and practice. Educational Researcher, 41(3), 93-97. http://dx.doi.org/10.3102/ $0013189 \times 12441244$

Parker, J. T. (2020). The Use of Battle Rap as a Way to Engage Students in STEM (Doctoral dissertation) Columbia University.

Petchauer, E. (2011). I feel what he was doin': Responding to justice-oriented teaching through hip-hop aesthetics. Urban Education, 46(6), 1411-1432. http://dx.doi.org/10.1177/ 0042085911400335

Poole, B. (2010). Commitment and criticality: Fairclough's critical discourse analysis evaluated. International Journal of Applied Linguistics, 20(2), 137-155. http://dx.doi.org/10.1111/j.1473-4192.2009.00234.x

Saracho, O. N., \& Spodek, B. (2007). Early childhood teachers' preparation and the quality of program outcomes. Early Child Development and Care, 177(1), 71-91. https://doi.org/10.1080/03004430500317366

Smith, A. (2020). Critical race theory: Disruption in teacher education pedagogy. Journal of Culture and Values in Education, 3(1), 52-71. https://doi.org/10.46303/jcve.03.01.4

Solorzano, D., Ceja, M., \& Yosso, T. (2000). Critical race theory, racial microaggressions, and campus racial climate: The experiences of African American college students. Journal of Negro Education, 69 (1/2), 60-73).

Stovall, D. (2006). We can relate: Hip-hop culture, critical pedagogy, and the secondary classroom. Urban Education, 41(6), 585-602. http://dx.doi.org/10.1177/ 0042085906292513

Tatum, A. W. (2000). Breaking down barriers that disenfranchise African American adolescent readers in low-level tracks. Journal of Adolescent \& Adult Literacy, 44(1), 52-64.

Tatum, A. W. (2008). Toward a more anatomically complete model of literacy instruction: A focus on African American male adolescents and texts. Harvard Educational Review, 78, 155-180. http://dx.doi.org/10.17763/haer.78.1.6852t5065w30h449

VanFossen, P. J. (2005). "Reading and math take so much time...": An overview of social studies instruction in elementary classrooms in Indiana. Theory \& Research in Social Education, 33(3), 376-403. http://dx.doi.org/10.1080/00933104.2005.10473287

Vlach, S. K. (2019). Literacy teachers' enactment of critical pedagogies with multicultural children's literature during interactive read aloud (Doctoral dissertation). University of Texas.

Vickery, A. E. (2017). You excluded us for so long and now you want us to be patriotic? African American women teachers navigating the quandary of citizenship. Theory \& Research in Social Education, 45, 318-348. https://doi.org/10.1080/00933104.2017.1282387

Wills, J. S. (2011). Misremembering as mediated action: Schematic narrative templates and elementary students' narration of the past. Theory \& Research in Social Education, 39(1), 115-144. http://dx.doi.org/10.1080/00933104.2011.10473449

Wilson, A. N. (1992). Awakening the natural genius of Black children. Afrikan World InfoSystems.

Winn, M. T. (2008). Black literate lives: Historical and contemporary perspectives. Routledge. 
Winn, M. T. (2010). "Betwixt and between": Literacy, liminality, and the "celling" of Black girls. Race, Ethnicity, and Education, 13(4), 425-447. http://dx.doi.org/10.1080/ 13613321003751601

Woodson, A. (2016). We're just ordinary people: Messianic master narratives and black youth's civic agency. Theory \& Research in Social Education, 44, 184-211. http://dx.doi.org/10.1080/00933104.2016.1170645

Wood, S., \& Jocius, R. (2013). Combating "I hate this stupid book!": Black males and critical literacy. The Reading Teacher, 66(8), 661-669. http://dx.doi.org/10.1002/trtr.1177

Yearta, L. (2019). Integrating Social Studies and English Language Arts: Digital Stories and the Revolutionary War. The Reading Teacher, 73(2), 215-218. http://dx.doi.org/ 10.1002/trtr.1806 